RESEARCH PAPER RP1401

Part of Journal of Research of the National Bureau of Standards, Volume 27, July 1941

\title{
AN IMPROVEMENT IN THE "PARTITION METHOD” FOR THE DETERMINATION OF BORON
}

\author{
By Francis W. Glaze and Alfred N. Finn
}

\section{ABSTRAC'T}

In a previous paper a method was described for the routine determination of boron in glass, based on the "partition" of boric acid between water and ether in the presence of hydrochloric acid and ethanol. In that method, barium, fluorine, iron, and zine interfere. It has now been found that the substitution of sulfuric acid for hydrochloric acid eliminates the interference of all of these elements except fluorine and gives results no less satisfactory than the previous method. Accordingly, the procedure reported in this paper should be substituted for the one originally described when one has occasion to determine boron in a glass of unknown composition or when the interfering elements are present.

\section{CONTENTS}

I. Introduction

II. Experimental study

III. Recommended method of analysis

1. Required reagents

IV. Analytical procedure C. An

\section{INTRODUCTION}

An earlier publication ${ }^{1}$ reported a method for the determination of boron in glass which depended on the "partition" of boric acid between the acidified water extract of the sodium carbonate fusion of the sample and an ether-ethanol mixture. Hydrochloric acid was used to acidify the water extract. It was found that barium, fluorine, iron, and zinc interfered. Inasmuch as sulfates are as a rule insoluble in ethanol, it was decided to substitute sulfuric acid for hydrochloric acid, hoping thereby to counteract the above interferences of barium, iron, and zinc.

\section{EXPERIMENTAL STUDY}

As hydrochloric acid (sp gr 1.18) is approximately $11.6 \mathrm{~N}$, sulfuric acid of that normality ${ }^{2}$ was used as a starting point; the above acid, diluted with an equal volume of distilled water, was used in place of the hydrochloric acid (1:1).

After several preliminary experiments showed promise, it was decided to determine the temperature effect before proceeding further. One-gram samples of sodium carbonate and measured volumes of a standard boric acid solution were added to calibrated, glass-

1 Francis W. Glaze and A. N. Finn, J. Research NBS 16, 421 (1936) RP882.

$232.3 \mathrm{ml}$ of sulfuric acid ( $\mathrm{sp}$ gr 1.84 ) made up to $100 \mathrm{ml}$. 
stoppered graduates, made just acid to $p$-nitrophenol with sulfuric acid (approximately $5.8 \mathrm{~N}$ ); and then $1 \mathrm{ml}$ of sulfuric acid (approximately $11.6 \mathrm{~N}$ ) was added. The volumes were adjusted to $25 \mathrm{ml}$ with distilled water, and then $25 \mathrm{ml}$ of absolute ethanol and $50 \mathrm{ml}$ of ether were added. The graduates were shaken at various temperatures between $20^{\circ}$ and $30^{\circ} \mathrm{C}$, the layers allowed to separate, and 50-ml aliquot portions of the ether-ethanol layers taken. The boron in each was determined, and the "partition coefficients" were calculated from the boron concentrations in the two layers. On plotting the coefficients, $k$, against the temperature, it was found that, in the range $20^{\circ}$ to $30^{\circ} \mathrm{C}$, the relation is linear and can be represented by the equation

$$
k=0.417-0.00232 t \text {. }
$$

In studying the effect of the various constituents under consideration, Standard Sample 93 (glass, high boron) of the National Bureau of Standards was used in most cases as the source of boron. The sample, plus the constituent being tested, weighed, in all cases, $0.5000 \mathrm{~g}$.

TABLE 1.-Results obtained for $\mathrm{B}_{2} \mathrm{O}_{3}$ in the presence of varying amounts of zinc, barium, iron, aluminum, and lithium

\begin{tabular}{|c|c|c|c|c|c|c|c|c|c|c|}
\hline \multirow{2}{*}{$\begin{array}{c}\begin{array}{c}\text { Experi- } \\
\text { ment } \\
\text { number }\end{array} \\
\end{array}$} & \multirow{2}{*}{ 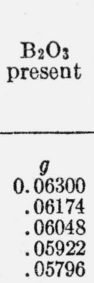 } & \multicolumn{2}{|c|}{$\begin{array}{c}\text { Constituent being } \\
\text { tested }\end{array}$} & \multirow{2}{*}{$\begin{array}{c}\begin{array}{c}\text { Extrac- } \\
\text { tion } \\
\text { tem- } \\
\text { pera- } \\
\text { ture }\end{array} \\
{ }^{\circ} C \\
24.0 \\
24.0 \\
24.0 \\
22.5 \\
25.0\end{array}$} & \multirow{2}{*}{$\begin{array}{l}\mathrm{Et}_{2} \mathrm{O} \\
\text { layer } \\
\\
m l \\
76.5 \\
76.5 \\
76.8 \\
76.5 \\
77.0\end{array}$} & \multirow{2}{*}{$\begin{array}{c}\begin{array}{c}\mathrm{H}_{2} \mathrm{O} \\
\text { layer }\end{array} \\
m l \\
21.9 \\
22.0 \\
21.7 \\
22.1 \\
21.6\end{array}$} & \multirow{2}{*}{$\begin{array}{c}k^{\prime} \text { (cal- } \\
\text { cu- } \\
\text { lated) }\end{array}$} & \multirow{2}{*}{$\begin{array}{c}\mathrm{B}_{2} \mathrm{O}_{3}{ }^{2} \\
\text { pres- } \\
\text { ent }\end{array}$} & \multirow{2}{*}{$\begin{array}{c}\mathrm{B}_{2} \mathrm{O}_{3}^{3} \\
\text { found }\end{array}$} & \multirow{2}{*}{ 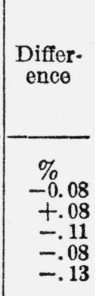 } \\
\hline & & \begin{tabular}{c}
$\mathrm{ZnO}_{2}$ \\
\hdashline do \\
\hdashline do \\
\hdashline do \\
\end{tabular} & $\begin{array}{c}g \\
\text { None } \\
0.01 \\
.02 \\
.03 \\
.04\end{array}$ & & & & & & & \\
\hline$\ldots$ & $\begin{array}{l}.05670 \\
.06300 \\
.05670 \\
.05040 \\
.04410\end{array}$ & $\begin{array}{c}\mathrm{BaO} \\
\mathrm{Ba} \\
\mathrm{do} \\
\mathrm{do}\end{array}$ & $\begin{array}{c}.05 \\
\text { None } \\
.05 \\
.10 \\
.15\end{array}$ & $\begin{array}{l}25.0 \\
25.0 \\
25.0 \\
24.5 \\
25.0\end{array}$ & $\begin{array}{l}76.9 \\
76.7 \\
76.6 \\
76.8 \\
76.7\end{array}$ & $\begin{array}{l}21.7 \\
21.6 \\
21.8 \\
21.7 \\
21.7\end{array}$ & $\begin{array}{l}.359 \\
.359 \\
.359 \\
.360 \\
.359\end{array}$ & $\begin{array}{r}11.34 \\
12.60 \\
11.34 \\
10.08 \\
8.82\end{array}$ & $\begin{array}{r}11.21 \\
12.55 \\
11.17 \\
10.09 \\
8.82\end{array}$ & $\begin{array}{l}-.13 \\
-.05 \\
-.17 \\
+.01 \\
\pm .00\end{array}$ \\
\hline 11. & $\begin{array}{l}.03780 \\
.06237 \\
.05985 \\
.05670 \\
.06880\end{array}$ & $\begin{array}{r}\mathrm{do} \\
\mathrm{Fe}_{2} \mathrm{O}_{3} \\
\mathrm{Al}_{2} \mathrm{O}_{3} \\
\mathrm{do}\end{array}$ & $\begin{array}{l}.20 \\
.005 \\
.025 \\
.05 \\
.025\end{array}$ & $\begin{array}{l}25.3 \\
25.3 \\
25.3 \\
26.0 \\
25.0\end{array}$ & $\begin{array}{l}76.7 \\
76.9 \\
76.8 \\
76.8 \\
77.7\end{array}$ & $\begin{array}{l}21.8 \\
21.3 \\
21.5 \\
21.5 \\
20.8\end{array}$ & $\begin{array}{l}.358 \\
.358 \\
.358 \\
.357 \\
.359\end{array}$ & $\begin{array}{r}7.56 \\
12.47 \\
11.97 \\
11.34 \\
13.76\end{array}$ & $\begin{array}{r}7.47 \\
12.39 \\
11.99 \\
11.43 \\
13.71\end{array}$ & $\begin{array}{l}-.09 \\
-.08 \\
+.02 \\
+.09 \\
-.05\end{array}$ \\
\hline 16 & .06880 & $\left\{\begin{array}{l}\mathrm{BaO} \\
\mathrm{Ba}\end{array}\right.$ & $\begin{array}{l}.025 \\
.05\end{array}$ & 25.0 & 77.4 & 21.1 & .359 & 13. 76 & 13. 77 & +.01 \\
\hline 17. & .06880 & $\left\{\begin{array}{l}\mathrm{Al}_{2} \mathrm{O}_{3-} \\
\mathrm{BaO}-\end{array}\right.$ & $\begin{array}{l}.025 \\
.15\end{array}$ & 25.3 & 77.5 & 20.8 & .358 & 13.76 & 13. 71 & -.05 \\
\hline 18. & .06880 & $\left\{\begin{array}{l}\mathrm{Al}_{2} \mathrm{O}_{3} \\
\mathrm{BaO}\end{array}\right.$ & $\begin{array}{l}.025 \\
.20\end{array}$ & 25.0 & 77.0 & 21.5 & .359 & 13.76 & 13.67 & -.09 \\
\hline $\begin{array}{l}19 . . \\
20 . .\end{array}$ & $\begin{array}{r}.06880 \\
.06880\end{array}$ & $\left\{\begin{array}{l}\mathrm{Al}_{2} \mathrm{O}_{3} \\
\mathrm{BaO}\end{array}\right.$ & $\begin{array}{l}.05 \\
.05 \\
.05\end{array}$ & $\begin{array}{l}24.5 \\
25.0\end{array}$ & $\begin{array}{l}77.9 \\
78.2\end{array}$ & $\begin{array}{l}20.5 \\
20.0\end{array}$ & $\begin{array}{l}.360 \\
.359\end{array}$ & $\begin{array}{l}13.76 \\
13.76\end{array}$ & $\begin{array}{l}13.74 \\
13.77\end{array}$ & $\begin{array}{l}-.02 \\
+.01\end{array}$ \\
\hline $21 \ldots$ & .06880 & $\left\{\begin{array}{l}\mathrm{Al}_{2} \mathrm{O}_{3} \\
\mathrm{BaO}\end{array}\right.$ & $\begin{array}{l}.05 \\
.10\end{array}$ & 23.0 & 77.9 & 20.2 & .364 & 13.76 & 13.76 & \pm .00 \\
\hline $22 \ldots$ & .06880 & $\left\{\begin{array}{l}\mathrm{Al}_{2} \mathrm{O}_{3}- \\
\mathrm{BaO}\end{array}\right.$ & .05 & 23.5 & 77.9 & 20.7 & .362 & 13.76 & 13.67 & -.09 \\
\hline & .06880 & $\left\{\begin{array}{l}\mathrm{Al}_{2} \mathrm{O}_{3-} \\
\mathrm{BaO}\end{array}\right.$ & $\begin{array}{l}.05 \\
20\end{array}$ & 25.0 & 77.9 & 20.5 & .359 & 13.76 & 13.81 & +.05 \\
\hline 24 & $\begin{array}{l}.00684 \\
.05650\end{array}$ & $\mathrm{Li}_{2} \mathrm{O}$ & .05 & $\begin{array}{l}26.0 \\
26.0\end{array}$ & $\begin{array}{l}78.3 \\
78.7\end{array}$ & $\begin{array}{l}20.7 \\
20.3\end{array}$ & $\begin{array}{l}.357 \\
.357\end{array}$ & $\begin{array}{r}1.37 \\
11.30\end{array}$ & $\begin{array}{r}1.32 \\
11.25\end{array}$ & $\begin{array}{l}-.05 \\
-.05\end{array}$ \\
\hline
\end{tabular}

$1 k=0.417-0.00232 t$.

2 On the assumption that the " $\mathrm{B}_{2} \mathrm{O}_{3}$ present" was in a $0.5000-\mathrm{g}$ sample of glass.

${ }^{3}$ Percentage of $\mathrm{B}_{2} \mathrm{O}_{3}=4\left(\mathrm{~B}_{2} \mathrm{O}_{3}\right)_{50} \mathrm{Et}_{2} \mathrm{O}\left[\mathrm{VE}_{\mathrm{E}_{2} \mathrm{O}}+\frac{\mathrm{V}_{\mathrm{H}_{2} \mathrm{O}}}{k}\right]$, where $\mathrm{V}_{\mathrm{E} t 2 \mathrm{O}}$ and $\mathrm{V}_{\mathrm{H} 2 \mathrm{O}}$ are the volumes of the ether-ethanol layer and the water layer, respectively, and $\left(\mathrm{B}_{2} \mathrm{O}_{3}\right){ }_{50} \mathrm{Et}_{2} \mathrm{O}$ represents the grams of $\mathrm{B}_{2} \mathrm{O}_{3}$ in the 50 -ml aliquot sample of the ether-ethanol layer. 
In the case of zinc, mixtures of zinc oxide and the sample were fused in a platinum crucible with $1 \mathrm{~g}$ of sodium carbonate, cooled, and neutralized with sulfuric acid (approximately $5.8 \mathrm{~N}$ ) to the $p$-nitrophenol end point. The boron in the resulting mixture (which contained some precipitated silica, etc.) was then determined. From table 1 , experiments 1 to 6 , it can be seen that, though there is a tendency for the results to be slightly low, they are reasonably satisfactory in the presence of as much as 10 percent of zinc oxide.

Because of its extensive use in optical glasses, barium oxide in amounts as high as 40 percent was added. As can be seen from experiments 7 to 11 , table 1 , the results are very satisfactory, except for experiment 8.

Although the very small amounts of iron ordinarily present in glass did not interfere in the original method, yet amounts equivalent to 1 percent of ferric oxide colored the ether-ethanol layer and masked the $p$-nitrophenol end point. However, amounts up to 10 percent do not interfere in the present modification, as can be seen from experiments 12 to 14 in table 1.

In experiments 15 to 23, NBS Standard Sample 80 (glass, sodalime) (no boron) was used as the glass and a standardized boric acid solution was added to the cooled melt. These tests show that alumina up to 10 percent in combination with barium oxide up to 40 percent does not interfere.

In the last two experiments, lithium equivalent to 10 percent of lithium oxide in the sample was added as the carbonate to NBS Standard Samples Nos. 128 and $93 . \quad$ The results indicate that lithium has no particular effect on the recovery of boron.

Inasmuch as some optical glasses contain lead, as well as barium and zinc, samples of such glasses were fused with sodium carbonate and a standardized boric acid solution was added. The range covered by these glasses was zinc oxide ( 0 to 8 percent), barium oxide ( 0 to 27 percent), and lead oxide ( 0 to 70 percent). The results by the recommended procedure are given in table 2 .

TABLE 2.-Determination of $\mathrm{B}_{2} \mathrm{O}_{3}$ in optical glasses containing barium, lead, and zinc

\begin{tabular}{|c|c|c|c|c|c|c|c|}
\hline \multicolumn{4}{|c|}{ Glass used contained- } & \multirow{2}{*}{\multicolumn{2}{|c|}{$\mathrm{B}_{2} \mathrm{O}_{3}$ added }} & \multirow{2}{*}{$\begin{array}{l}\text { Added } \\
\mathrm{B}_{2} \mathrm{O}_{3} \\
\text { found }\end{array}$} & \multirow{2}{*}{$\begin{array}{c}\text { Differ } \\
\text { ence }\end{array}$} \\
\hline $\mathrm{BaO}$ & $\mathrm{PbO}$ & $\mathrm{ZnO}$ & $\mathrm{B}_{2} \mathrm{O}_{3}$ & & & & \\
\hline $\begin{array}{c}\% \\
31.6 \\
40.7 \\
\text { None }\end{array}$ & $\begin{array}{c}\% \\
\text { None } \\
\text { None } \\
\text { None }\end{array}$ & $\begin{array}{l}\% \\
7.5 \\
7.7 \\
1.8\end{array}$ & $\begin{array}{r}\% \\
3.77 \\
5.82 \\
11.16\end{array}$ & $\begin{array}{c}g \\
0.0344 \\
.0275 \\
.01376\end{array}$ & $\begin{array}{r}\% \\
6.88 \\
5.50 \\
2.75\end{array}$ & $\begin{array}{c}\% \\
6.94 \\
5.64 \\
2.76\end{array}$ & $\begin{array}{r}\% \\
+0.06 \\
+.14 \\
+.01\end{array}$ \\
\hline 14. 9 & 23.8 & 8.0 & None & $\begin{array}{l}0362 \\
0724\end{array}$ & $\begin{array}{r}\text { 7. } 24 \\
14.48\end{array}$ & $\begin{array}{r}7.12 \\
14.47\end{array}$ & $\begin{array}{l}-.12 \\
-01\end{array}$ \\
\hline $\begin{array}{l}\text { None } \\
\text { None }\end{array}$ & $\begin{array}{l}45.6 \\
51.4\end{array}$ & $\begin{array}{l}\text { None } \\
\text { None }\end{array}$ & $\begin{array}{l}\text { None } \\
\text { None }\end{array}$ & $\begin{array}{l}0362 \\
.0724\end{array}$ & $\begin{array}{r}7.24 \\
\text { 14. } 48\end{array}$ & $\begin{array}{r}7.28 \\
14.38\end{array}$ & $\begin{array}{l}+.04 \\
-.10\end{array}$ \\
\hline None & 69.4 & None & None & $\begin{array}{l}.0362 \\
.0724\end{array}$ & $\begin{array}{r}7.24 \\
14.48\end{array}$ & $\begin{array}{r}7.26 \\
14.53\end{array}$ & $\begin{array}{l}+.02 \\
+.05\end{array}$ \\
\hline
\end{tabular}

The interference caused by fluorine has not yet been overcome.

\section{RECOMMENDED METHOD OF ANALYSIS}

\section{REQUIRED REAGENTS}

1. Paranitrophenol. One gram dissolved in $75 \mathrm{ml}$ of ethanol $(95$ percent) and made up to $100 \mathrm{ml}$ with distilled water. 
2. Phenolphthalein. One gram dissolved in $100 \mathrm{ml}$ of ethanol (95 percent) and made up to $200 \mathrm{ml}$ with distilled water.

3. Hydrochloric acid, $0.5 N$.

4. Sodium hydroxide, carbon dioxide and boron free, $0.5 \mathrm{~N}$, and stored in containers free from boron.

5. Barium hydroxide, $0.1 N$.

6. Ethanol, absolute.

7. Ethyl ether, aldehyde and peroxide free (as indicated by test given below).

8. Mannitol.

\section{ANALYTICAL PROCEDURE}

Mix $0.5000 \mathrm{~g}$ of glass and $1.000 \mathrm{~g}$ of sodium carbonate intimately together in a mortar and transfer to a platinum crucible. Fuse at as low a temperature as possible and only as long as is necessary to effect complete decomposition. Cool, wash the lower surface of the lid, catching the washings in the crucible, and wash down the inside of the crucible with hot distilled water. Disintegrate the melt on the bath with the aid of a platinum wire and concentrate to about $5 \mathrm{ml}$. Cool and neutralize most of the alkali with $\mathrm{H}_{2} \mathrm{SO}_{4}$ (approximately 5.8 $N$ ), guarding against loss of boron both by spattering and by volatilization. Add two drops of $p$-nitrophenol, complete neutralization dropwise, add $1 \mathrm{ml}$ of $\mathrm{H}_{2} \mathrm{SO}_{4}$ (approximately $11.6 \mathrm{~N}$ ), and transfer to a calibrated $100-\mathrm{ml}$ glass-stoppered cylinder. Dilute to $25 \mathrm{ml}$, add $25 \mathrm{ml}$ of absolute ethanol and $50 \mathrm{ml}$ of ether, ${ }^{3}$ and shake intermittently for 20 minutes, noting the temperature. Allow the layers to separate, record their volumes, transfer $50 \mathrm{ml}$ of the ether layer to a $250-\mathrm{ml}$ Erlenmeyer flask, add two drops of $p$-nitrophenol, and titrate to the $p$-nitrophenol end point with $0.5 \mathrm{~N} \mathrm{NaOH}$. Read the burette, add 1 $\mathrm{ml}$ of phenolphthalein, and continue the titration to the phenolphthalein end point. Add a volume of $0.5 \mathrm{~N} \mathrm{NaOH}$ equal to three times that used between the two end points and shake the flask vigorously. Wash down the inside of the flask with distilled water and make the water volume up to 40 to $50 \mathrm{ml}$. Boil off the ether and ethanol as quickly as possible, ${ }^{4}$ first on a water or steam bath and finally over a free flame. Adjust the volume to 35 to $45 \mathrm{ml}$, cool, and then make just acid with $0.5 \mathrm{~N} \mathrm{HCl}$. Warm on the steam bath for about 1 minute, and boil under reduced pressure until cool to remove $\mathrm{CO}_{2}$. Titrate to the $p$-nitrophenol end point with $0.1 \mathrm{~N}$ $\mathrm{Ba}(\mathrm{OH})_{2}$, record the burette reading, add mannitol, and titrate the $\mathrm{B}_{2} \mathrm{O}_{3}$. One milliliter of $0.1 \mathrm{~N} \mathrm{Ba}(\mathrm{OH})_{2}$ is equivalent to $0.00348 \mathrm{~g}$ of $\mathrm{B}_{2} \mathrm{O}_{3}$. A blank determination should be made using a glass, preferably similar to the ones being analyzed, but containing no boron (such as Standard Sample 80 of the National Bureau of Standards).

\footnotetext{
3 It became evident during the course of this work that the quality of the ether used in this method must be examined at frequent intervals and should be purified if the $p$-nitrophenol end point is not sharp. A satisfactory test method is to treat approximately $50 \mathrm{ml}$ of ether, $5 \mathrm{ml}$ of $0.5 \mathrm{~N} \mathrm{NaOH}$, and about $50 \mathrm{ml}$ of distilled water exactly as a sample would be treated for the removal of ether and ethanol. Upon diluting to 35 to $45 \mathrm{ml}$ and neutralizing with $0.5 \mathrm{~N} \mathrm{HCl}$ to the $p$-nitrophenol end point, no color should be evident. For purification, a modification of the method of S. Palkin and H. R. Watkin (Ind. Eng. Chem. 21, 863 (1929)) was used. The ether was first agitated with asbestos impregnated with alkaline permanganate (5 ml of saturated $\mathrm{KMnO}_{4}$ to $15 \mathrm{ml}$ of 33 -percent $\mathrm{NaOH}$ ) and then slowly siphoned, in a very fine stream, through a column of the alkaline permanganate and into a bottle. This bottle also contained asbestos impregnated with alkaline

permanganate and was kept in a cool, dark place. $p$-nitrophenol end point in the final titration.
} 
The equation for calculating the percentage of $\mathrm{B}_{2} \mathrm{O}_{3}$ in a $0.5000-\mathrm{g}$ sample is as follows:

$$
\text { Percentage of } \mathrm{B}_{2} \mathrm{O}_{3}=4\left(\mathrm{~B}_{2} \mathrm{O}_{3}\right)_{50 \mathrm{Et}_{2} \mathrm{O}}\left[V_{\mathrm{Et}_{2} \mathrm{O}}+\frac{V_{\mathrm{H}_{2} \mathrm{O}}}{k}\right] \text {, }
$$

where $\left(\mathrm{B}_{2} \mathrm{O}_{3}\right)_{50} \mathrm{Et}_{2} \mathrm{O}$ represents the grams of $\mathrm{B}_{2} \mathrm{O}_{3}$ in the $50-\mathrm{ml}$ aliquot portion taken for analysis, and $V_{\mathrm{Et}_{2} \mathrm{O}}$ and $V_{\mathrm{H}_{2} \mathrm{O}}$ are the volumes of the ether layer and the water layer, respectively. The value of $k$ in the above is found from the equation

$$
k=0.417-0.00232 t \text {. }
$$

By means of this method, it has been possible to determine amounts of $\mathrm{B}_{2} \mathrm{O}_{3}$ as low as 0.30 and as high as 16.00 percent.

\section{CONCLUSION}

The substitution of sulfuric acid for the hydrochloric acid originally recommended overcomes the interference of certain elements, such as barium, iron, and zinc, and gives results no less satisfactory. Although it is not known whether or not lead interferes in the original method, it does not in the present modification. It is thought that the method described above should be substituted for the one originally described by us, when one has occasion to determine boron in a glass of unknown composition or when barium, iron, zinc, or lead is present.

Washington, May 13, 1941. 